\section{Economic and financial determinants of bankrupcy: evidence from Ecuador's private banks and the impact of dollarization on financial fragility}

\author{
Adriana Uquillas ${ }^{1}$ \\ ${ }^{1}$ National Polytechnic School, Department of Mathematics, Quito, Equador \\ Francis Flores ${ }^{2}$ \\ ${ }^{2}$ National Polytechnic School, Department of Quantitative Economics, Quito, Equador
}

Received on:

08/04/2019

Approved on:

05/19/2020

Responsible Editor:

Prof. Dr. Ilidio Lopes

\section{Evaluation process:}

Double Blind Review

\begin{abstract}
Purpose - An econometric model is established to explain bankruptcy in Ecuadorian banks. The utility of combining macroeconomic, financial, and idiosyncratic determinants to explain bankruptcy is empirically demonstrated.

Design/methodology/approach - The cross-sectional analysis includes 24 banks between 1996 and 2016. Bankruptcy is considered as a rare event.

Findings - Even in adverse macroeconomic conditions, the main factor explaining bankruptcy is lax administration. Also, those banks with higher levels of indebtedness with respect to their capital levels are more susceptible to bankruptcy. Higher levels of spread and lower inflation are associated with lower levels of bankruptcy. Ceteris paribus, after dollarization the bankruptcy probability decreases and the effective management of each bank becomes a relevant factor to explain bankruptcy.
\end{abstract}

Originality/value - Different determinants are combined in order to produce predictive models with practical value and macro-dependent dynamics that are relevant for stress tests. There is empirical evidence that the change in the monetary system has helped to stabilize the financial system. The problem of having a small sample and rare events is evident and adequately addressed.

Keywords -bankruptcy, dollarization, rare event, small sample, financial crisis

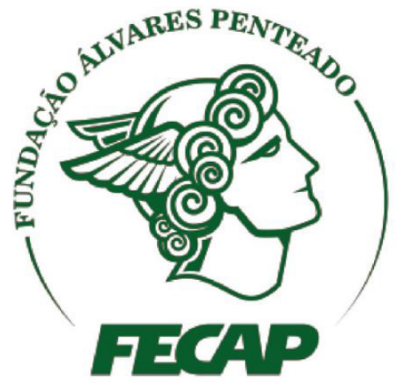

Revista Brasileira de Gestáo de Negócios

https://doi.org/10.7819/rbgn.v22i4.4080 


\section{INTRODUCTION}

Banking crises have resulted in costly losses for the countries that have faced them; the effects of a systemic failure in the financial sector are multiple, generally affecting the country's economy and the banks' credibility. In Ecuador, the late 1990s saw the largest financial crisis in the country. According to Naranjo (2003), the 19981999 recession culminated in general bankruptcy of the country's financial system and resulted in 15 of the 40 existing banks, two financial companies, and one mutual entity disappearing or being taken over by the state; the economic crisis represented a cost of more than $80 \%$ of that year's GDP. In addition, according to figures from the Central Bank of Ecuador (BCE, 2008), between August 1998 and August 1999, the banks' liquidity decreased from US $\$ 1.6$ billion to US\$ 860 million and the pastdue portfolio increased by $300 \%$, from US\$300 million to US\$ 1.1 billion. Total deposits decreased by 33\% from US\$ 5.1 billion to US\$ 3.4 billion. The way out of this crisis was a change in the monetary system and the official dollarization of the economy was the viable alternative found to establish stability and growth in the country.

In fact, following the implementation of official dollarization in the Ecuadorian economy, the country experienced a period of relative economic stability. However, the country's current economic situation is different, due to the international financial crisis in 2009 and, mainly, the considerable drop in the oil price in 2015. Furthermore, the appreciation of the dollar, added to high public expenditure by the government, has generated particular difficulties in the country's economy.

This research aims to develop a bankruptcy early warning model, up to one year in advance in the case of Ecuador. Its interest lies in making use of more robust inferential statistical methodologies that adapt to and study the dynamics of Ecuador's economic and financial system, characterized by a small number of operating banks, a low probability of bank failure, and marked by the adoption of official dollarization in 2000, which caused a structural shock to the Ecuadorian economy. The aforementioned aspects have not been previously addressed altogether by the literature, hence the need to carry out this study.

It is important to highlight that the variable that represents bank failure is subjective as there are several criteria used in its definition, representing a difficulty in the study. The definition of bankruptcy adopted in this investigation will be established later in section 3 . Idiosyncratic aspects of banks, as well as systemic and macroeconomic factors, are analyzed in order to develop an econometric study. Furthermore, in the technical aspect, the problem of having a small sample (approximately 26 banks on average in the last 20 years) and the existence of rare events, that is, binary dependent variables with tens of thousands of times fewer events (bankruptcy) than nonevents (no bankruptcy), is made evident and adequately addressed. Papers such as those by Yang et al. (2011), Huang et al. (2012), and Zhou et al. (2014) address the issue of small sample size using the support vector machine (SVM) technique, confirming the special ability of this technique to perform well in terms of prediction using a small dataset. However, SVM models are quite complicated to understand because the coefficients that are assigned to the variables are difficult to interpret (Tseng, \& $\mathrm{Hu}$, 2010; Jeong et al., 2012; Alaka et al., 2018).

On the other hand, as pointed out by Alaka et al. (2018) (in a systemic review of 49 articles published between 2010 and 2015 using the Web of Science, Business Source Complete, and Engineering Village databases, on methodologies used in investigations that aim to predict and explain the determining factors of business bankruptcy), the coefficients estimated in a logistic regression represent variable importance. Therefore, the result is transparent and helps users to identify the key problem areas of a company in bankruptcy, which is precisely one of the objectives of this study. Nevertheless, in addition to the articles reviewed by Alaka et al. (2018), there is a vast amount of literature where it has been made explicit that situations of rare events and small samples are difficult to explain and predict using the logistic regression method by means of traditional estimation (for example: Firth (1993), Peduzzi et al. (1996), and Gao (2007)). Thus, we propose estimating the parameters using the method proposed by Firth (1993). This is an estimation method that has not been used in previous investigations of this type and that makes an important contribution to the work, as the underestimation of the probability of rare events (bankruptcy) is corrected by substituting the popular statistical procedure of logistic regression estimation with a method that provides unbiased estimates of the probability of bankruptcy. In addition, it corrects the estimation of the coefficients by considering the presence of a small sample and rare events and preserves the interpretative power of the method. 
Currently, the Ecuadorian financial system is composed of private banks (24 in total), state entities, financial societies, savings and credit unions, and mutual fund societies. The private banking system specifically plays an important role in national economic development. According to the Association of Private Banks of Ecuador, by January 2016, both deposit and credit operations represented more than half of the national GDP (58.28\%).

The period of this study encompasses the years from 1996 to 2016. That is, it covers a period before dollarization and another after dollarization, which allows the study of the effect of dollarization on bank fragility and makes evident the contrast of hypotheses of structural change and their due treatment, which are results that are presented for the first time in this type of study. In this way, there is a relevant analysis of the transformations in the country's banking fragility in the context of dollarization.

The main results show that even in the face of adverse macroeconomic conditions, the main factor affecting the probability of bank failure in Ecuador is lax management and administration within the institutions. In addition, those banks with higher levels of debt relative to their capital levels are more susceptible to bankruptcy. Higher net interest income is associated with lower levels of bankruptcy probability. The higher the inflation, the higher the probability of bankruptcy. After dollarization, the probability of bankruptcy decreases and the management efficiency in terms of control and risk management of each banking institution becomes a relevant factor in explaining bankruptcy.

The established model is one more tool for the supervisor to use in their effort to achieve efficient control that leads to a more solid and strengthened financial system, since it provides early warning signals about the deterioration of a financial institution in order to take corrective measures and reduce the risk of bankruptcy and subsequent bank contagion.

The rest of the article is structured as follows: section 2 presents a literature review; section 3 describes the methodology and available data; section 4 presents the empirical results; and finally, section 5 concludes the work.

\section{LITERATURE REVIEW}

Interest regarding the issue of financial system risk gained momentum beginning in the Great Depression of the 1930s in the United States, where it initially sought to determine the factors that influenced the bankruptcy of companies through the analysis of financial indicators. Later works such as that of Altman (1968), who carried out a study through a multiple discriminant analysis to determine the probability of bankruptcy of companies in the United States, emerged and proved to provide a good classification model for active companies.

Regarding the type of variables that have been considered to carry out studies related to bankruptcy models in different economic sectors, Hernández and Wilson (2013) establish that based on annual observations of listed companies during the period $1980-2011$, it is possible to establish the usefulness of combining accounting, market, and macroeconomic data to explain the risk of corporate bankruptcy. The performance of the estimated models is compared with models built using a neural network and against Altman's (1968) original Z-score specification.

On the other hand, Oliveira et al. (2015) collects information from the Federal Deposit Insurance Corporation (FDIC) on 11,121 United States banks from 2000 to 2014, and identifies the main determinants for bank failure. The authors include the set of CAMELS indicators - capital, asset quality, management, earnings, liquidity, sensitivity to market risk - and other variables such as credit risk, taxes, income on assets, and institution size. The results point to the importance of CAMELS indicators to explain bank failures associated with the last financial crisis in the United States.

In a review of methodological approaches used in bankruptcy prediction models, Alaka et al. (2017) point out the need to consider industry dynamism, the imperfection of financial variables, and the social factors that actually explain the financial situation of companies. The authors establish that most studies in this field have only used financial indices or ratios in combination with other observable financial variables, such as stock market information. Only about 3\% of bankruptcy studies include non-financial variables. Of the two main studies that use non-financial variables, Horta and Camanho (2013) combine three strategic variables (main company activity, company size, and geographical location) with six financial indices, obtaining good performance results from the proposed model. The authors conclude that financial variables alone are insufficient for an early description of bankruptcy and that it is essential to consider adverse management actions and other social factors in this type of study. 
Finally, Alaka et al. (2018) develop a theoretical framework to identify the important qualitative and quantitative factors needed to develop a high-performance bankruptcy model. The results show that the important quantitative factors are profitability, liquidity, leverage, management efficiency, and cash flow; while important qualitative variables are management characteristics, internal strategy, company characteristics, and macroeconomic and sustainability factors. These factors are aligned with existing insolvency theories such as Porter's five competitive forces and the 5Ps of Mintzberg's strategy (plan, tactics, pattern, position, and perspective) (Mintzberg, H., 1987).

In Latin America, these types of study are quite scarce, and even globally there are still open theoretical and empirical questions. In the case of Ecuador, of the models that focus on detecting financial vulnerability in an economy through early warning models, Ayala (1999) analyzes the probability of crisis in the Ecuadorian financial system and tries to establish the warning signs prior to a financial crisis using a regression model and a signal approach. A crisis period is understood to be one in which private banks enter into credit operations with the Central Bank of Ecuador under the protection of segment $\mathrm{C}$ of articles 24 and 25 of the Monetary Regime Law. Ayala points out the possibility that the balance sheets of financial institutions are subject to configurations that do not reflect the seriousness of the problem. The model reflects the limited importance of accounting indicators in the months immediately prior to a crisis and their significance in other periods. Thus, for example, in the two months prior to a crisis, the system's financial indicators do not provide any warning signal, in contrast to the variables of the macroeconomic environment; the deterioration of the provision coverage indicator and the interest rate ratio is evident only one semester before the crisis; and the deterioration in the levels of leverage and administrative management could be a sign of a crisis eight to ten months after the symptom is presented, even if these indicators do not reflect it in the months immediately prior to the problem exploding. On the other hand, the greatest effects on the probability of a crisis would come from variations in the profitability of productive assets and in liquidity.

In addition, Lafuente (2001) analyzes the macro and microeconomic conditions under which the 1999 banking crisis in Ecuador unfolded and, using duration models, establishes the dynamics and main causes of bank collapse. The model estimates suggest that the most important factors affecting the probability of bankruptcy in times of financial stress are the inadequate management of asset, liquidity, and the rapid growth of past due loans. More recent studies, within the same research line, include those by Paez (2014) and Arias (2015). Páez constructs a model of the financial fragility of the Ecuadorian financial system in the period 2003-2012. In that study, the concept of fragility refers specifically to a period $\mathrm{x}$-state before bankruptcy; therefore, the more fragile a financial entity is, the greater the probability that it will become insolvent and actually go bankrupt. Unlike the study carried out here, that paper does not capture the particular characteristics of each bank. Among the variables that most explain the degree of fragility of the banking system are gross domestic product (GDP), oil prices, and the movement of public debt stock in relation to GDP. In addition, the level of default, internal efficiency, and illiquidity pressure (liquid assets over total assets) stand out.

On the other hand, Uquillas (2018) studies the macro and microeconomic determinants for credit risk stress tests. Credit risk is directly related to the risk of bankruptcy of a financial institution. The results suggest that shocks are rapidly transmitted in Ecuador. Risk is negatively sensitive to liquidity and the intermediation rate, but its impacts and speed of transmission are different. Oil prices, credit volume, and economic activity are relevant determinants for Ecuador.

Finally, Arias (2015) carries out an analysis of the financial system using a financial vulnerability index. The financial vulnerability index is an instrument that makes it possible to measure possible risk situations in the financial system in advance. The reduction of this index results in greater solidity of the system. This vulnerability indicator of the Ecuadorian banking system is based on 12 indicators that the Andean Community of Nations considers for vulnerability analysis. Among these factors are the financial deepening index, leverage, financial intermediation, solvency, default, and liquidity.

Regarding statistical methodologies, Mselmi et al. (2017) compare the performance of logit models, artificial neural networks, support vector machine techniques, and a hybrid model that integrates the support vector machine with partial least squares, when predicting financial difficulties of small and medium-sized French companies. The empirical results indicate that one year before financial difficulties, support vector machines are the best classifier, with an overall accuracy of $88.57 \%$. 
Two years before financial difficulties, the hybrid model outperforms other methodologies, with an overall accuracy of $94.28 \%$. It is indicated that distressed companies are smaller, have more leverage, and have a lower repayment capacity. Furthermore, they have lower liquidity, profitability, and solvency ratios.

On the other hand, Hafiz A. Alaka et al. (2018) show how eight prediction methods based on 13 key criteria work within the area of research on bankruptcy prediction models. These tools include two statistical ones: multiple discriminant analysis and logistic regression; and six artificial intelligence tools: artificial neural networks, vector support machines, approximate sets, case-based reasoning, decision trees, and genetic algorithms. The 13 identified criteria include precision, transparency of results, fully deterministic results, data size capability, data dispersion, required variable selection method, applicable variable types, and more. In general, no single tool was found to be predominantly better than the other tools relative to the 13 identified criteria. It is concluded that an overall better performance model can only be found through a hybrid model integrating several tools, thus coinciding with the finding of Mselmi et al. (2017).

The previously mentioned studies show a high percentage of correct classification in the "bankruptcy" and "non-bankruptcy" groups. However, these studies do not perform as well in the case of finite samples and rare events. Lee, Booth, and Alam (2005, p. 5) were able to demonstrate that artificial neural networks can still function reasonably well with a small sample as long as "a target vector is available." However, this method does not allow for any interpretation of the factors that determine financial failure or bankruptcy. On the other hand, the method almost universally used to calculate event probabilities, and which allows for parameter interpretation, is logit analysis and this is suboptimal under these conditions (King, 2001; Firth, 1993; Gao, 2007).

A small sample and rare event is precisely the Ecuadorian case and therefore the predictions of bank failure should consider these two aspects. For this purpose, estimates are made using the method proposed by Firth (1993), a method of parameter estimation that has not been used in previous research of this type, according to the literature review. In addition, idiosyncratic, financial, and macroeconomic determinants are combined to produce models with predictive accuracy, practical value, and macrodependent dynamics that are relevant to stress testing. In order to select the variables and perform sampling in the case of rare events, qualitative criteria supported by the literature and bibliographic review were combined with quantitative criteria supported by the processes proposed by Foster and Stine (2004), Zhang et al. (2013), and King (2001).

\section{THEORETICAL FRAMEWORK / METHODOLOGY}

Bankruptcy laws and theories have provided guidelines for addressing the problem of bankruptcy and the rights of stakeholders (both debtors and nondebtors). However, knowledge of theories is not enough for business survival; arising from the various bankruptcy theories is the pragmatic need to be able to predict the onset or possible onset of a financial crisis in an entity. In fact, as seen in the previous section, the prediction of bankruptcy has attracted the interest of many academics.

The problem of bank failure is understood by Korobkin (1991) as a crisis of various values and not only one of debt recovery. Precisely, the theoretical basis supporting this research is the value-based theory proposed by this author, which explains the emergence of bankruptcy law as a system with wide-ranging forms, proportions, and magnitudes. Korobkin (1991) argues that the issues to be addressed when talking about bankruptcy are multidimensional, encompassing social, political, economic, and even moral extensions. Furthermore, he mentions that the study of bankruptcy must be comprehensive in order for its participants to obtain optimal value. This theory also states that a company is not a mere set of static and lifeless assets, but an entity with personality. That is, a business can change its personality, and how its personality changes affects people in ways that are not only economic. The theory frames the different possibilities of increases in and loss of assets. Like a human debtor, the resources available for distribution are imbued with social, political, and moral characteristics; they change over time, circumstances, and at different rates throughout their lifetimes. It is therefore clear that it is difficult to offer the same panacea for problems that arise at different stages of the debtor's estate, because each financial difficulty is unique in its historical context.

On the other hand, as mentioned above, the variable that represents bank failure is subjective in nature since there are several criteria used in its definition. Caprio and Klingebiel (2003) point out that a crisis situation is when the non-productive portfolio (ratio between past 
due portfolio and gross total portfolio) is greater than a certain threshold, while works such as that of Kaminsky and Reinhart (1999) determine a crisis period as being when there is greater state intervention and/or a greater number of bank closures. An alternative definition is suggested by Demirguc-Kunt and Detragiache (1997), where a crisis episode is defined as being when at least one of the following conditions occurs: (1) the ratio of non-performing assets to total assets exceeds $10 \%$; (2) the cost of the bailout operation is at least $2 \%$ of GDP; (3) problems in the banking sector lead to large-scale nationalization of banks; (4) there are widespread bank runs or deposit freezes, prolonged bank closures, or widespread deposit guarantees by the government in response to the crisis.

Rojas-Suárez (1998), in turn, considers four definitions of banking crises: (1) periods in which the ratio of past due loans to the total portfolio of the system is greater than the average during a calm period plus two standard deviations; (2) periods in which the system loses at least $5 \%$ of its deposits; (3) periods in which the crisis index that combines the previous two exceeds the system average during a calm period plus two standard deviations; (4) periods of intervention by the authorities, either by closing banks, recapitalizing institutions using public resources, or strongly injecting liquidity.

In this work, bankruptcy is defined as an institution's intervention, liquidation, or declaration of bankruptcy (Lafuente, 2001).

Figure 1 illustrates the historical monitoring of the number of banks in the period from 1996 to 2016. As can be seen, in the pre-dollarization stage - evidenced by strong financial liberalization - the number of banks grew rapidly, and following the economic and financial crisis of the late 1990s, approximately one third of the number of institutions went bankrupt and underwent restructuring and reorganization processes by the Central Bank.

Following the implementation of official dollarization in the Ecuadorian economy, the Ecuadorian financial system has shown a relatively stable behavior, with two isolated cases of bankruptcy, which involved Banco Territorial and Banco Sudamericano in 2013 and 2014, respectively.

As previously mentioned, a logistic regression model with parameter estimation using the Firth method is employed to explain bank failure (Firth, D, 1993). This is a discrete choice model with a binary dependent variable (bankruptcy or no bankruptcy), which we will denote as $\mathrm{Y}$. The probability of the event is modeled using the cumulative logistic distribution function, which we will denote as $\mathrm{F}$.

The analysis of binary choice models involves modeling a latent variable - an unobservable or nonquantifiable variable - that indicates the index or propensity for the occurrence of an event or may represent the difference in terms of utility between one option and another (Greene, 2012).

The underlying model of the latent variable $y^{*}$ is determined by:

$y_{i}^{*}=\beta_{0}+\beta_{1} x_{i 1}+\ldots+\beta_{k} x_{i k}+\mu_{i}$

or in its matrix form

$y_{i}^{*}=X_{i} \beta+\mu_{i}$,

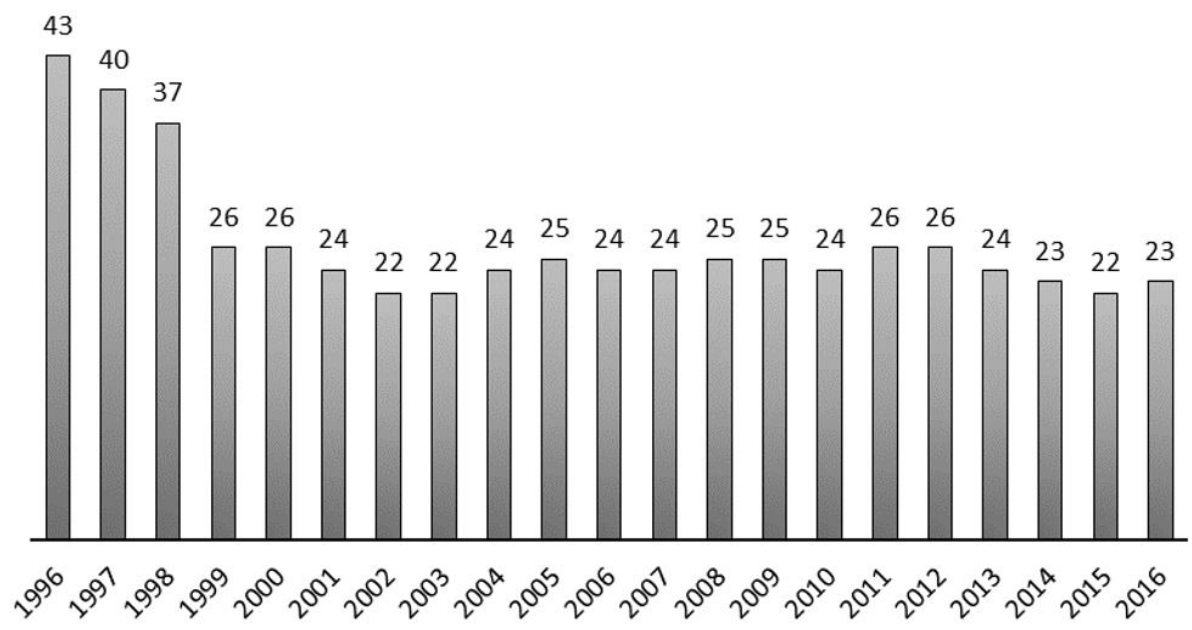

Figure 1 - Evolving banking system of Ecuador 1996-2016 
where for each observation $i,(i=1 \cdots n), x_{i 1}, x_{i 2} \ldots x_{i k}$ are the explanatory variables of the model, $\beta_{0}, \beta_{1} \ldots \beta_{k}$ represent the coefficients to estimate associated with those variables, and for each observation $i, \mu_{i}$ is the error term, $X_{i}$ is a dimension vector $1 \mathrm{x} \mathrm{k}$, where each component corresponds to the $k$ explanatory variables of the individual $i$, and $\beta$ is the vector of the $k$ parameters.

If at the moment of modeling the latent variable exceeds a certain level, the response variable is equal to 1 , and if this does not happen, it is equal to 0 . Therefore, the dichotomous model is expressed as:

$y_{i}=\left\{\begin{array}{lll}1, \text { if } y_{i}^{*}>0 & \text {,that is } & X_{i} \beta+\mu_{i}>0 \\ 0, \text { if } y_{i}^{*}<0 & \text {,that is } & X_{i} \beta+\mu_{i}<0\end{array}\right.$

The probabilistic model is defined as follows: $E(Y i \mid X i)=P(Y i=l \mid X i)=P\left(y_{i}^{*}>0\right)=F\left(\beta_{0}+\beta_{l} x_{i l}+\ldots+\beta_{K} x_{i K}\right)$

Therefore, the higher the value of $\mathrm{yi}^{*}$, the higher the probability of the event occurring.

\section{I Estimation by maximum likelihood}

For the estimation of binary variable models, the maximum likelihood method is indispensable since it is based on the distribution of the dependent variable conditioned by the explanatory variables (Wooldridge, 2010).

The joint density function of $y_{1}, y_{2}, \cdots, y_{n}$, in order to obtain the maximum likelihood estimator, is given by:

$$
P\left(Y_{i}=y_{i} \mid p_{i}\right)=\prod_{i=1}^{n}\left(\left(F\left(X_{i} \beta\right)\right)^{y_{i}}\left(1-F\left(X_{i} \beta\right)\right)^{l-y_{i}}\right.
$$

The log likelihood function is obtained by applying the logarithm to the previous equation:

$$
l_{i}(\beta)=\sum_{i=1}^{n}\left[y_{i} \log F\left(x_{i} \beta\right)+\left(1-y_{i}\right) \log \left(1-F\left(x_{i} \beta\right)\right)\right]
$$

Generalizing, the log of the likelihood function for an n-sized sample will be:

$$
L(\beta)=\sum_{i=1}^{n} l_{i}(\beta)
$$

The maximum likelihood estimator is the one that maximizes equation (7), which by definition is obtained when the log likelihood gradient is zero (Greene, 2012).

The procedure for obtaining the coefficients of the estimators is iterative. The estimators obtained by maximum likelihood in logistic regression are consistent, but are not asymptotically unbiased; that is, they present problems when faced with small samples and the presence of rare events (King, 2001).

\subsection{Specification of the logistic regression model through estimation of parameters by the Firth method}

The principle governing the Firth maximum likelihood estimation method is to penalize the maximum likelihood estimation by means of a penalty term. The penalized verisimilitude function is given by:

$L^{*}(\beta)=L(\beta)|i(\beta)|^{1 / 2}$

where $|i(\beta)|^{1 / 2}$ represents the penalty function for the bias problem and is known as Jeffrey's invariant term. The logarithm of the extended likelihood function is therefore:

$$
l_{i}^{*}(\beta)=l_{i}(\beta)+\frac{1}{2} \log |i(\beta)|
$$

When $i(\beta)$ has a k-dimension, $i(\beta)$ is the Fisher information matrix.

The estimation of the Firth logistic regression model provides a penalized maximum likelihood estimator that is also unique in that both the curve of the likelihood function and the logarithm of the determinant of the Fisher matrix are concave (Equation 9). For more details on this, see Firth (1993).

The term penalization in the likelihood function is sensitive to a change in sample size $n$ and the presence of rare events; therefore, estimation through the introduction of the term penalization produces unbiased estimators even in cases with a small sample and very few events (Gao, 2007). Furthermore, the estimators obtained are consistent; that is, as the sample size increases, the estimator converges to the real value of the event (Williams, 2017).

\subsection{Estimation and data}

In order to estimate the model, information was extracted from official sources such as the monthly and quarterly national account bulletins from the Central Bank of Ecuador (BCE in Spanish) and the National Institute of Statistics and Censuses (INEC in Spanish); and monthly balance sheets published by the Department of Banking (SBS in Spanish).

Data from 1996 to 2016 for the months of January, April, July, and October of each year were taken into consideration for the development of the model. The validation period for the model includes the months not considered in the development period. Appendix A indicates the list of operating banks during 1996-2016. 


\subsection{Definition of the dependent variable}

There is vast literature aimed at delimiting the dependent variable of bank failure considering that it is a qualitative-type variable with a degree of subjectivity. According to the definition proposed by Lafuente (2001), the dependent variable is defined as follows:

$Y_{i}=\left\{\begin{array}{c}1 \text { if the financial institution was intervened in }, \\ \text { liquidated, or declared bankrupt. } \\ 0 \text { otherwise }\end{array}\right.$

Case $Y_{i}=1$ includes both remediation and restructuring processes.

\subsection{Relationship between the economic and banking environment during the period I996-20I6}

Several studies point out the value of combining accounting, market, strategic, and qualitative variables as well as macroeconomic factors to explain the risk of corporate bankruptcy (Korobkin, 1991; Hernández and Wilson, 2013; Alaka et al., 2017; Horta and Camanho, 2013; Alaka et al., 2018). Seven variables were considered in the CAMELS group.

\subsection{Macroeconomic environment variables:}

These correspond to the indicators at an aggregate level of a nation's economy. The theoretical foundation indicates that in an unstable or weak macroeconomic situation, the impact of this on the financial system is negative, exacerbating financial crises.

\subsubsection{Financial market variables:}

These refer to factors specific to the banking system. They are those indicators that refer to the behavior of the financial system as a whole and are not specific to each institution.

\subsubsection{Bank idiosyncratic variables:}

These refer to indicators specific to each banking institution. CAMELS and non-CAMELS factors are included.

The independent variables were chosen according to the literature studied, as well as considering the availability of information in Ecuador's public databases. The following macro variables were considered: monthly inflation, oil price, annual GDP growth, consumption restriction, and the balance of trade with respect to GDP (Fischer, 1993; Uquillas, 2018).

Among the financial system variables considered were financial spread, IDEAC (Conjunctural Economic Activity Index in English)/credit, GDP/credit, funding, leveraging, liquidity, GDP/fundraising, capital and reserves/loan volume, and portfolio delinquency (Ayala, 1999; Páez, 2014; Arias, 2015).

Finally, the variables considered at an idiosyncratic level were: productive assets/total assets, productive assets/ cost-generating liabilities, bank size, capital and reserves/ assets, annual results/assets, annual results/equity, gross portfolio/total assets, annual results/volume of the credit system, funding, leveraging, portfolio delinquency, coverage of delinquent loans, operating expenses/financial margin, ROE, ROA, and liquidity index (Oliveira et al. 2015; Lafuente, 2001; González-Hermosillo, 1999; Mselmi et al., 2017).

Appendix B lists the exogenous variables considered together with their description, source, and calculation formula. Some of the macroeconomic, financial, and idiosyncratic factors considered in this study are described in detail below.

\subsubsection{Macroeconomic environment factors}

\subsubsection{Monthly Inflation:}

This is understood to be the monthly change in the general price level. In Figure 2, the highest peak of inflation corresponds to the month of January 2000, with a value of $14.33 \%$, a situation that had an impact on people's purchasing power.

Monthly inflation is expected to have a positive relationship with the rate of arrears, since a stable macroeconomic structure is associated with a low rate of inflation (Fischer, 1993).

\subsubsection{Banking System Variables}

\subsubsection{Financial Spread:}

Also known as the financial intermediation index, this measures the margin included in the interest rates of active and passive operations managed by the financial institution. Private bank operation interest rates from 84 to 91 days were used.

Deterioration of the factor, as can be seen in the months prior to the 2000 crisis (Figure 3), indicates that 


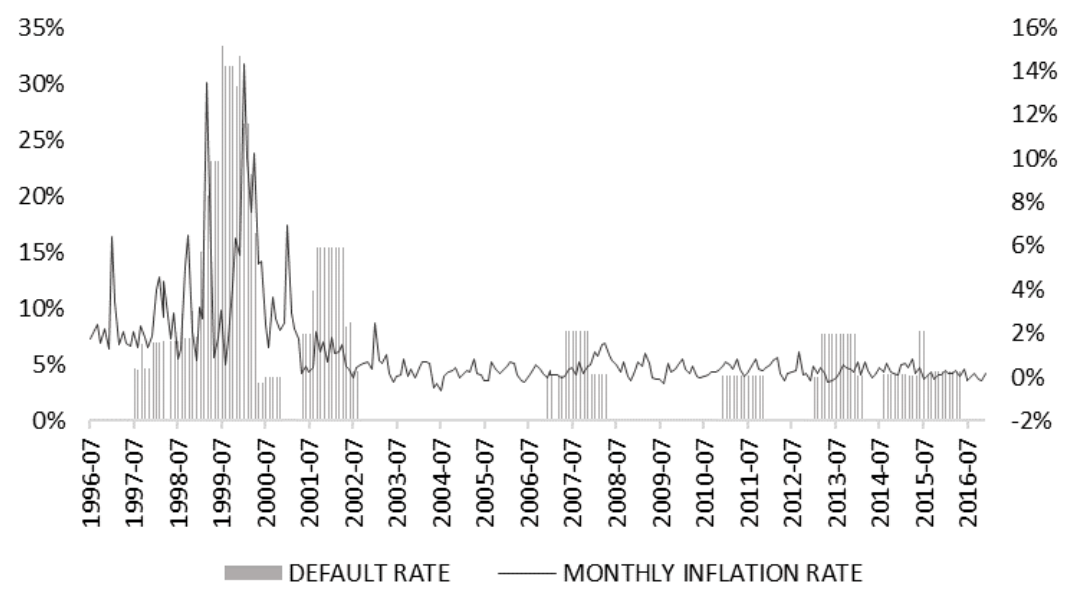

Figure 2 - Evolutionary monthly inflation and default rate of the private banking system 1996-2016

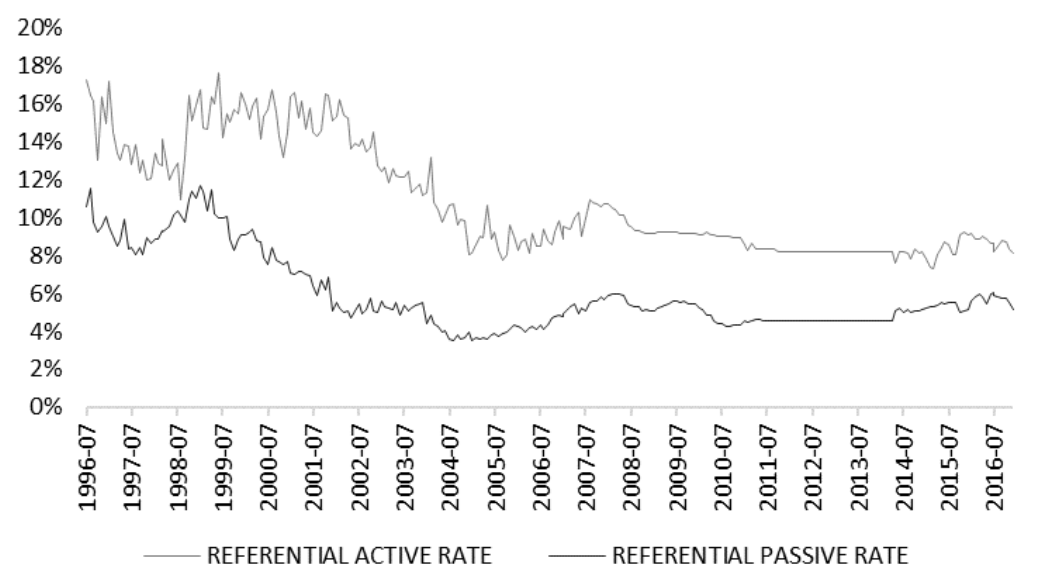

Figure 3 - Evolutionary financial spread 1996-2016

the bank presents greater difficulty in coping with and responding to the resources taken in from its depositors, so that the expected relationship between the indicator and the bankruptcy rate will be inverse, with increases in the probability of bankruptcy as a result of reductions in the net interest margin and reductions in the probability of bankruptcy as the rate differential improves.

\subsubsection{Leveraging:}

This measures the degree of indebtedness of the financial institution with respect to its equity. It is defined as the ratio of liabilities to the institution's own capital.

As Figure 4 shows, in 1999 there was an abrupt momentary recovery of the indicator, and as of 2000, the indicator shows a recovery to its usual levels, showing relatively stable behavior in the post-dollarization stage.
The drop in the indicator could have been due to two reasons: a decrease in the institutions' liabilities or an increase in equity. The first did indeed take place in local banks, given the support given by the central bank to institutions in trouble.

\subsubsection{Idiosyncratic indicators in banks}

\subsubsection{ROE:}

This factor measures the degree of profitability generated by the assets of an institution. The higher the indicator, the better the situation of the institution, since investment that goes hand in hand with an expansion of the business is encouraged.

On the other hand, lower levels can generate disincentives for shareholders by issuing alerts and signs of a deterioration in the business. 
Figure 5 illustrates the relationship between the bankruptcy rate and financial return (ROE). A linear relationship is observed between the explanatory variable and the response variable. An inverse relationship between both variables can be seen, where a higher $\mathrm{ROE}$ value corresponds to lower bank failure, while a lower profitability indicator is associated with a higher number of banks in a situation of financial fragility.

\section{3·5.6.2 Non-performing Loan Rate:}

This indicator refers to the balance of nonproductive loans of the institution in relation to the total gross portfolio.

The grouping of portfolio delinquencies by deciles (Figure 6) corroborates what is evidenced by the theory, where a higher bankruptcy rate is associated with a higher delinquency rate, because an increase in this indicator represents greater exposure of the institution to bankruptcy in the short term (González-Hermosillo, 1999).

\subsection{Econometric analysis of bank failure in Ecuador}

Based on an initial model of financial fragility, the presence of structural change due to dollarization was analyzed using Chow's structural change test (Wooldridge, 2010). The existence of a structural shock was statistically verified both before and after dollarization. To address this situation, we proceeded to include a control variable associated with dollarization and interaction of each of the explanatory variables with it.

To select the variables, qualitative criteria supported by the relevant literature and a bibliographic review were combined with quantitative criteria, adapting the processes proposed by Foster and Stine (2004) and by

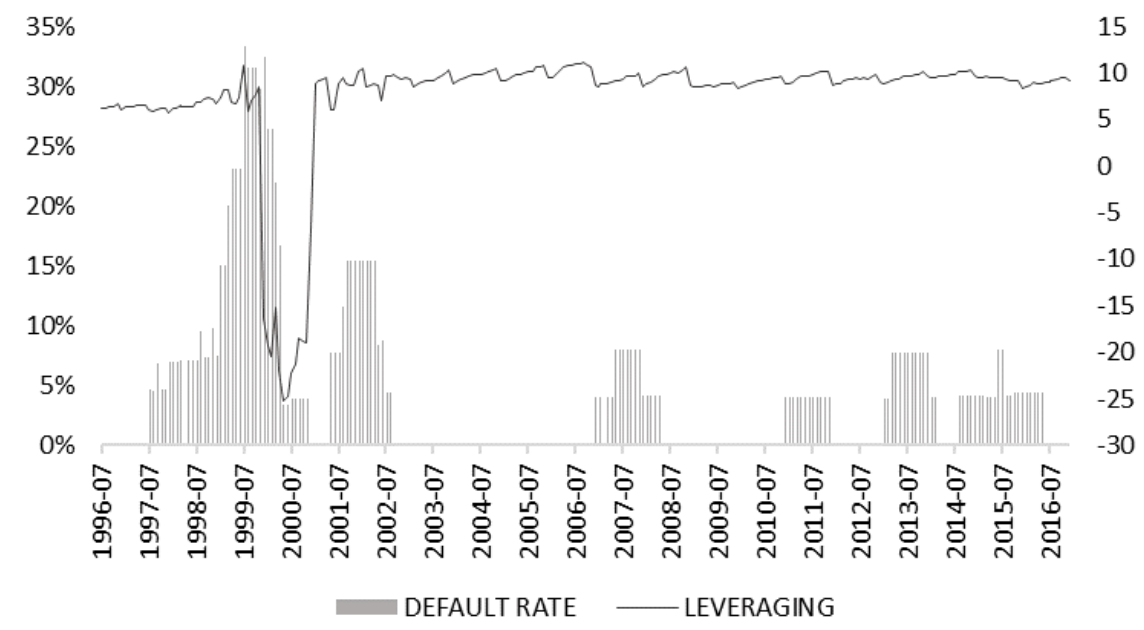

Figure 4 - Leveraging of the financial system and default rate

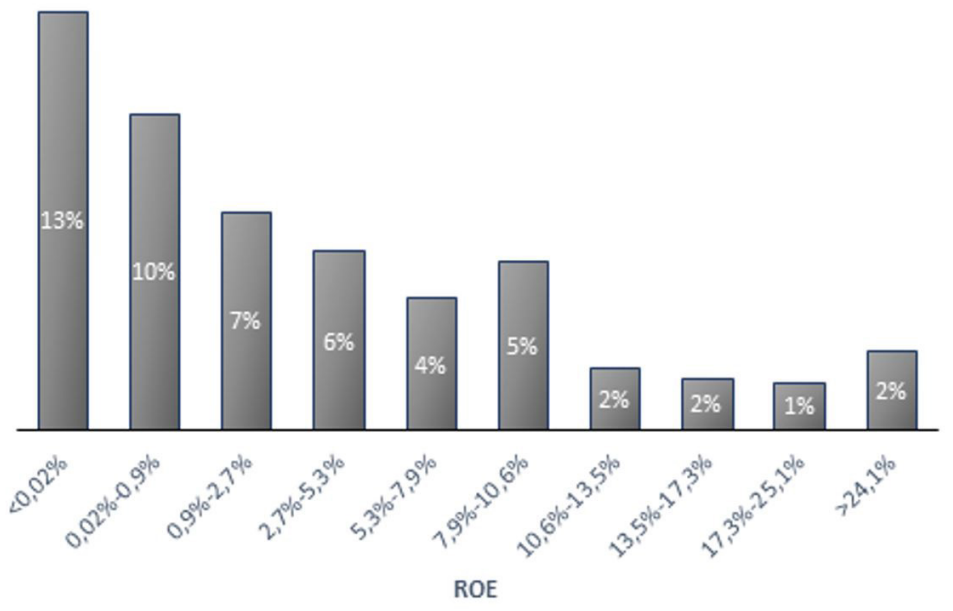

Figure 5 - Bank bankruptcy rate based on ROE 


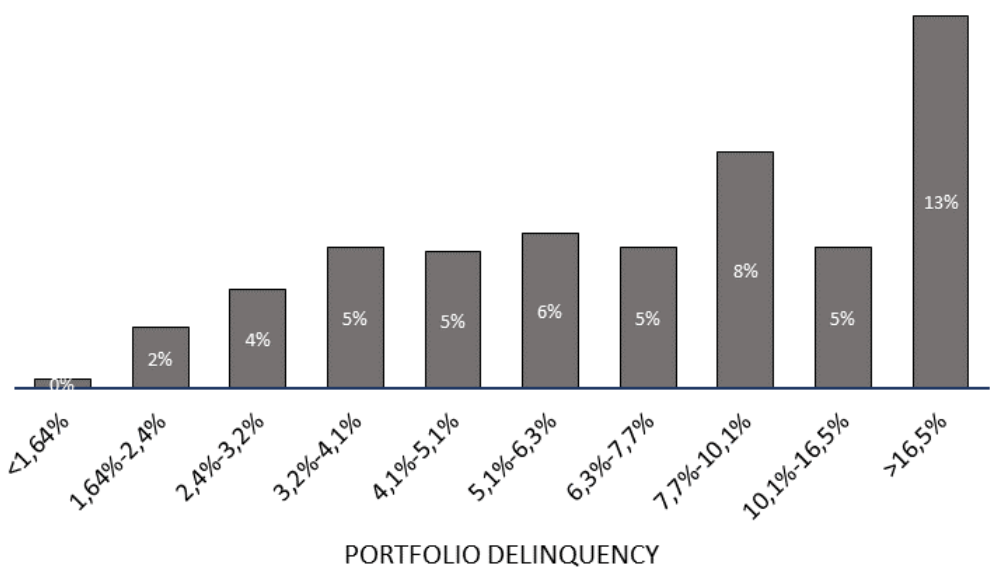

Figure 6 - Portfolio delinquency by deciles versus bankruptcy rate.

Zhang et al. (2013). A four-stage procedure was established that essentially consists of: (1) organizing calculations to allow interactions, (2) sequentially selecting the most important variables by means of the forward procedure, (3) conservatively considering a level of statistical significance of up to $10 \%$ to handle scattered data and binary responses, and (4) choosing the most parsimonious model in terms of the number of explanatory variables present that make economic sense and have statistical significance.

A correct model specification analysis was performed, considering the omission of relevant variables or the inclusion of irrelevant variables, the incorrect linear functional form, heteroscedasticity, and multicollinearity. Also carried out were: a correct result classification table test, which consists of a tool used in the evaluation of the goodness of fit of logistic regression models; and a likelihood ratio test, based on a comparison between the value of the estimated unrestricted model of the likelihood function versus the restricted model (Wooldridge, 2010; Green, 2012).

In addition, an analysis of the ROC curve of the model, which represents sensitivity in function of specificity, was included, where the sensitivity of the model is interpreted as the estimated percentage of bankrupt institutions, in relation to those that really went bankrupt; on the other hand, the specificity of the model indicates the percentage of bankrupt financial institutions that the model predicts, compared to those institutions that did not fail.

Finally, the Kolmogorov Smirnov (KS) test was used to evaluate the model's performance in terms of its ability to discriminate between bankruptcy and nonbankruptcy (Anderson, 2007).

\section{RESULTS AND DISCUSSION}

The resulting model equation is explicitly detailed in equation 10:

$P($ Financial institution goes bankrupt in the following 12 months $\mid X)=\frac{e^{(Z)}}{1+e^{(Z)}}$

where:

$\mathrm{X}$ is the model's independent variables vector, that is, $\mathrm{X}=$ (Dollarization, Delinquency, ROE, Leverage, Spread, Inflation);

$Z=-0.478-2.289^{*}$ Dollarization +

$5.179 *$ delinquency $*$ dollarization -

$3.500 *$ Roe $^{*}$ dollarization +

$0.107 *$ difappeasement -

$32.623 *$ Spread $+10.729 *$ Inflation;

Dollarization: Binary control variable that takes the value 0 before dollarization and 1 after dollarization;

delinquency*dollarization: Idiosyncratic variable that measures the individual effect of dollarization on the portfolio's delinquency rate;

ROE* dollarization: Idiosyncratic variable that measures the individual effect of dollarization on the return on equity; difappeasement: Systemic variable of first-differentiation leveraging;

Spread: Systemic variable of financial spread;

Inflation: Macroeconomic variable of monthly inflation.

Table 1 shows in detail the description of each independent variable of the resulting model in (10) together with its respective source and calculation formula. Table 2 shows the estimation results.

It was necessary to exclude some macroeconomic, systemic, and idiosyncratic variables of each financial 
Table 1.

Description of each exogenous variable of the model

\begin{tabular}{lcc}
\hline \multicolumn{1}{c}{ Exogenous Variable } & Source & \multicolumn{1}{c}{ Calculation Formula } \\
\hline $\begin{array}{l}\text { Dummy variable used to measure the precise } \\
\text { impact of dollarization on the probability } \\
\text { of bankruptcy of a financial institution. The }\end{array}$ & Own Preparation & $D=\left\{\begin{array}{c}0, \text { before dollarization } \\
1, \text { after dollarization }\end{array}\right.$ \\
dummy dollarization variable considers the \\
official adoption date of the new monetary \\
regime in the Ecuadorian economy, so it takes \\
the value 1 as of the year 2000, and the value 0 \\
the year before 2000.
\end{tabular}

the year before 2000

\section{Inflation}

Macroeconomic variable indicating the continuous and sustained rise in the general level of prices normally measured by the consumer price index (CPI). Has a monthly periodicity.

The CPI is an economic indicator that measures the evolution of the general level of prices corresponding to a set of consumer items (goods and services) purchased by households in the country's urban area.
National Institute of Statistics and Censuses

https://www.ecuadorencifras.gob.ec

INFLATION $_{t}=\left(\frac{C P I_{t}}{C P I_{t-1}}-1\right) \times 100$

Where:

$\mathrm{CPI}_{t}$ : Consumer Price Index at time t.

Banco Central del Ecuador (Central $C P I_{t-1}$ : Consumer Price Index at time ${ }^{t-1}$. Bank of Ecuador)

https://www.bce.fin.ec
Financial Spread

Also known as "financial intermediation margin." Systemic variable that is defined as the difference between the active interest rate (lending rate) and the passive rate (borrowing rate) of interest.

These are the net profits generated by the financial intermediation business. Its periodicity is monthly.

\begin{tabular}{|c|c|c|}
\hline Leveraging & & \\
\hline $\begin{array}{l}\text { Indicator of the level of indebtedness of an } \\
\text { organization in relation to its assets. It is } \\
\text { measured as the relationship between the debts } \\
\text { and the equity of the financial institution. } \\
\text { Leverage is a variable of the financial system } \\
\text { that refers to the effect that indebtedness has on } \\
\text { profitability. It has a monthly periodicity. }\end{array}$ & $\begin{array}{c}\text { Superintendencia de Bancos } \\
\text { Banking Superintendency } \\
\text { https://www.superbancos.gob.ec }\end{array}$ & $\begin{array}{l}\text { APPEASEMENT } T_{t}=\frac{P A S_{t}}{P A T_{t}} \\
\text { Where: } \\
P A S_{t}: \text { Represents liabilities in a given period t. } \\
P A T_{t}: \text { Represents the equity in a given period t. } \\
L E V E R A G E_{t}: \text { Corresponds to the leverage } \\
\text { variable in its first difference. }\end{array}$ \\
\hline \multicolumn{3}{|l|}{ Portfolio delinquency } \\
\hline $\begin{array}{l}\text { The Portfolio delinquency coefficient is used to } \\
\text { detect problems with the quality of assets in the } \\
\text { portfolio. } \\
\text { The idiosyncratic indicator of portfolio } \\
\text { delinquency measures the portion of the } \\
\text { total portfolio that has past due installments, } \\
\text { therefore, it does not generate interest or } \\
\text { income. It has a monthly periodicity. }\end{array}$ & $\begin{array}{c}\text { Banking Superintendency } \\
\text { https://www.superbancos.gob.ec }\end{array}$ & $\begin{array}{l}\text { DELINQUENCY } Y_{t}=\frac{C I_{t}}{C T B_{t}} \\
\text { Where: } \\
C I_{t}: \text { Non-productive portfolio in a given period } t \text {. } \\
C T B_{t}: \text { Total Gross Portfolio in a given period }{ }^{t} \text {. }\end{array}$ \\
\hline \multicolumn{3}{|l|}{ ROE } \\
\hline $\begin{array}{l}\text { Idiosyncratic indicator that measures the } \\
\text { profitability of the equity, in other words, it } \\
\text { measures the patrimonial return with respect } \\
\text { to the net profits of the entity. Therefore, } \\
\text { higher values of this indicator represent better } \\
\text { conditions for the entity. It has a monthly } \\
\text { periodicity. }\end{array}$ & $\begin{array}{l}\text { Central Bank of Ecuador } \\
\text { https://www.bce.fin.ec }\end{array}$ & $\begin{array}{l}R O E_{t}=\frac{R E_{t}}{P P_{t}} \\
\text { Where: } \\
R E_{t}: \text { Result of the period at time }{ }^{t} \\
P P_{t}: \text { Average equity at time }{ }^{t} .\end{array}$ \\
\hline
\end{tabular}

$$
\begin{gathered}
\text { Superintendencia de Bancos } \\
\text { Banking Superintendency }
\end{gathered}
$$

$T A_{t}$ : Active interest rate in a given period $\mathrm{t}$.

$T P_{t}$ : Passive interest rate in a given period $\mathrm{t}$.

\section{$S P R E A D_{t}=T A_{t}-T P_{t}$}

Where:

https://www.superbancos.gob.ec 
Table 2.

\section{Bankruptcy model estimated using the Firth method}

\begin{tabular}{ccc}
\hline TYPE & INDICATORS & COEF. \\
\hline Control & Dollarization & $-2.289^{* * *}$ \\
& & $(0.323)$ \\
Idiosyncratic & delinquency*dollarization & $5.179^{* * *}$ \\
& & $(1.238)$ \\
& ROE*dollarization & $-3.500^{* * *}$ \\
Financial & & $(1.065)$ \\
System & Leveraging in first difference & $0.107^{* *}$ \\
& & $(0.044)$ \\
Macroeconomics & Spread & $-32.623^{* * *}$ \\
& & $(9.734)$ \\
& Inflation & $10.729^{*}$ \\
& & $(5.433)$ \\
& Interceptor & -0.478 \\
& & $(0.395)$ \\
& Observations & 1951 \\
\hline
\end{tabular}

Robust standard errors in parentheses

${ }^{* * *} \mathrm{P}<0.01 .{ }^{* *} \mathrm{P}<0.05 .{ }^{*} \mathrm{P}<0.1$

institution, such as oil price, liquidity index, and coverage of the non-performing portfolio, among others, due to the non-significance and high presence of multicollinearity.

The coefficient associated with dollarization is negative, i.e., ceteris paribus, upon the adoption of dollarization, the probability of bankruptcy of banking institutions in Ecuador decreases. These results are defined based on the conclusions established by Bedri and Selahattin (2014) and Naranjo (2018), where the effect of dollarization on the Ecuadorian economy is studied and both works point out that once dollarization is implemented, Ecuador's macroeconomic performance improves, changing the country's money-price ratio. In fact, the adoption of the measure represented a process of relative economic and financial stability for the country three years after its implementation (Naranjo, 2003), as opposed to periods of political and economic instability that occurred with greater force in the late 1990s. In addition, when performing an economic stability analysis between 2000 and 2015, M. Naranjo Chiriboga (2018) finds that the dollarization regime, since it imposes monetary rigidity and clear limits on discretion, has generated remarkable macroeconomic stability, in addition to sustained growth, income recovery, and a reduction of poverty.

Note that the dollarization variable indicates a general (economic) effect on the probability of bank failure, while the variables that represent the interaction of the indicators with the dollarization variable (idiosyncratic variables) show the individual effect of the adoption of the measure with respect to each indicator of the financial institutions, that is, the fluctuations in the indicators due to dollarization. In times of dollarization, the idiosyncratic factors of each bank clearly explain the probability of bankruptcy of the institution. The empirical results contribute to the theoretical analyses carried out by Calvo (2001) and Minda (2005), where the need for in-depth empirical assessments is determined to define how and in which sectors the currency change contributed.

The ROE profitability ratio also exhibits a negative effect on the bank's probability of bankruptcy, a result that is consistent with the literature and means that a higher level of profitability of the institutions reduces the probability of their bankruptcy. As expected, the portfolio default ratio has a positive coefficient. This suggests that higher levels of delinquency are associated with a greater effect on the probability of bankruptcy of the financial institution, as found by González-Hermosillo (1999).

With regard to the systemic variables, both the degree of leverage and the net interest margin were significant. The positive sign of the leverage ratio means that those banks with higher levels of indebtedness relative to their capital levels to cope with them are more susceptible to bankruptcy. The financial intermediation margin variable, on the other hand, negatively influences the probability of bankruptcy of the financial institution; that is, a higher difference in the interest rates of banking operations is associated with lower levels of financial crisis. These results that are aligned with several previous works, including those of Ayala (1999), Paez (2014), and Arias (2015).

Among the group of macroeconomic variables, the one that highlights and helps to explain financial fragility is inflation. Greater change in the general price level is related to greater economic instability (Fischer, 1993; Uquillas, 2018); therefore, a positive coefficient for the indicator would be expected, which is actually obtained in the model.

With regard to the correct specification of the model, we first proceeded with the analysis of the correlation matrix between the variables related to the financial fragility event and then analyzed the existence of multicollinearity in the model. Multicollinearity refers to the degree of correlation between the independent variables within the model. That multicollinearity can cause low levels of significance and high standard errors. Wooldridge (2010) states that as the degree of multicollinearity increases, the estimators will become less accurate and stable.

In order to identify the presence of multicollinearity in this study, the correlation between the exogenous variables 
was analyzed using the variance inflation factor (VIF), which indicates a serious multicollinearity problem if its value is greater than 10 . For this investigation, the VIF turned out to be 1.5. From this analysis, it is concluded that the model does not contain multicollinearity problems.

The existence of heteroscedasticity in the model was also statistically confirmed. To correct for this situation, the model was estimated with robust standard errors. As for the omitted variable issue, the Ramsey reset test carried out indicates the presence of variable omission in the model. This may be related to the lack of available information regarding some variables, but which were taken into account by other authors such as Oliveira et al. (2015), where they mention that one factor that affects bank failure is the ratio of loan loss coverage to total assets, which consists of a reserve for loan and lease losses that is adequate to absorb the estimated credit losses associated with the loan and leasing portfolio.

Using the estimated model, it is possible to individually identify which banks would be on alert. In general, the proposed model correctly predicts $95 \%$ of the observations.

The area under the ROC (AUROC) curve has become a standard performance evaluation criterion in two-class pattern recognition problems. Figure 7 shows the ROC curve, where the true positive rates (sensitivity) are found on the $\mathrm{Y}$ axis and the true negative rates (1-specificity) are set on the $\mathrm{X}$ axis.

A value greater than 0.7 is considered to be a very strong case of discrimination (Anderson, 2007). The proposed model presents a ROC value of 0.82 .

Finally, one of the main reasons behind the study of bank failure is to develop models that are capable of detecting early signals in those financial institutions with a higher probability of showing signs of this possibility, thus allowing the relevant authority to act preventively.

Figure 8 shows bankruptcy rate predictions over time for private banks in Ecuador. The fragility alert state of the financial system that we establish (continuous gray line) is the point where specificity and sensitivity are

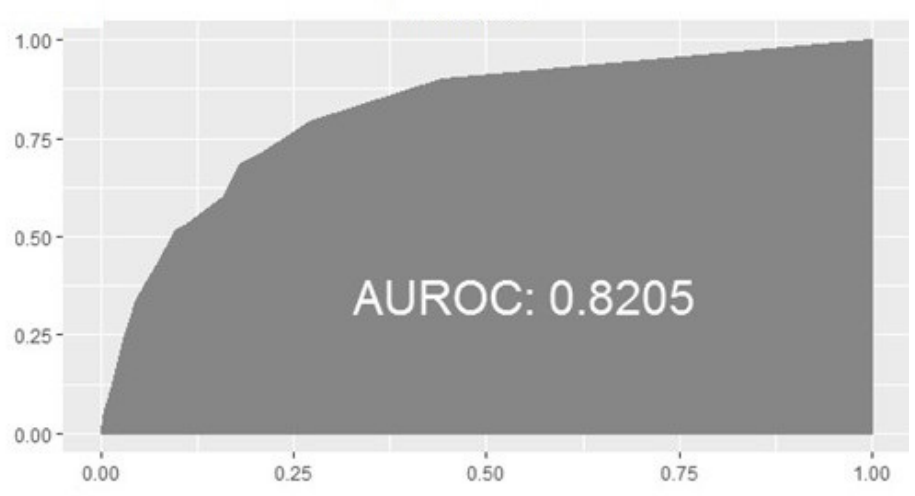

Figure 7 - ROC curve validation sample

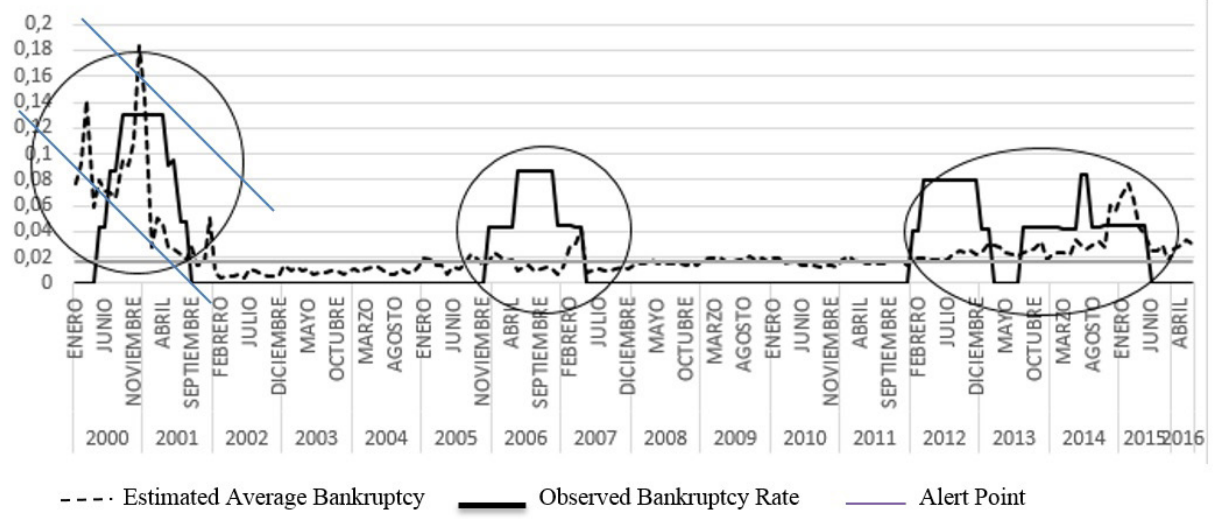

Figure 8 - Estimated fragility states of the national financial system: real vs. projected bankruptcy rate of Ecuador's private banks 
maximized, reaching values of $68 \%$ and $83 \%$, respectively. It is based on this value that the model sets off a bank fragility alert. As observed in the graph, the estimated alert periods coincide with actual periods of bank fragility. As already mentioned, standard logistic regression estimation provides biased estimators, which translates into very small estimators that result in an underestimation of the probability of occurrence of the rare event (King, 2001). Thus, the predicted values of bank fragility using the Firth estimation method are better adjusted than those of the standard logistic regression, especially for the case of Ecuador, where not only a rare event but also a small sample are evident.

\section{CONCLUSIONS}

The financial turmoil in Ecuador in the late 1990s led to significant losses for the country's economic and financial system, as well as a high bankruptcy rate of financial institutions, drawing attention from academics and policymakers. Using a sample of 24 banks and their monthly behavior, this paper investigates and empirically demonstrates the usefulness of combining idiosyncratic information from the financial system and macroeconomic indices to explain the risk of bank failure. The benefit of combining accounting data, market data, and strategic variables, as well as macroeconomic factors, to explain the risk of corporate bankruptcy is framed within other theoretical and empirical findings such as those of Korobkin (1991), Hernández and Wilson (2013), Horta and Camanho (2013), and Alaka et al. (2018).

The estimation of parameters using the maximum likelihood method in logistic regression may sharply underestimate the probability of rare events, even more so in small samples. Therefore, in this paper, corrections are applied that go beyond existing methods and modify the estimates of risk factors. Second, commonly used data collection strategies are extremely ineffective for rare event data. Fear of collecting data with too few events has led to data collections with large numbers of observations but relatively few poorly measured explanatory variables (Peduzzi et. al., 1996). As a result, a more efficient sampling is proposed, following the logic of King (2001) and Foster and Stine (2004) and designing valid differences of information, allowing us to collect much more significant explanatory variables.

The results are consistent with previously published works: inflation, financial spread, and the degree of leverage of each bank are the characteristics that explain the probability of bankruptcy of banks (Ayala, 1999; Paez, 2014; Arias, 2015). In relation to leverage, those banks with higher levels of indebtedness with respect to their capital levels needed to face them are more susceptible to bankruptcy. On the other hand, higher levels in the difference in interest rates for banking operations are associated with lower levels of financial crisis. In other words, the financial intermediation margin has a negative influence on the probability of bankruptcy.

Among the group of macroeconomic variables, greater change in the general price level is related to greater economic instability (Fischer, 1993; Uquillas, 2018).

As already mentioned, the authors are unaware of any other work that has studied the effect of dollarization on bank failure; this is another contribution of this work. The theoretical analyses carried out by Calvo (2001) and Minda (2005) indicate that dollarization has advantages and disadvantages, so it is necessary to make in-depth empirical assessments to determine how and in which sectors the exchange rate contributed.

The main findings that emerged regarding the effects of dollarization on financial institution failure are: 1) Given the existence of structural change, the dollarization variable indicates a general effect on the probability of bank failure, while the interaction of the idiosyncratic variables and dollarization show the individual effect of the adoption of the measure, that is, the fluctuations in the indicators due to dollarization. The coefficient associated with dollarization is negative, which is in line with what would be expected based on empirical evidence, that is, ceteris paribus, under the adoption of dollarization, the probability of bankruptcy of banking institutions in Ecuador decreases. Bedri and Selahattin (2014) state that once dollarization was implemented, Ecuador's macroeconomic performance improved, changing the money-price ratio in the country. These results are consistent with the evidence found by Naranjo (2018), who studies the effect of dollarization on the Ecuadorian economy between 2000 and 2015. In other words, the results obtained in this work are robust to several empirical specifications; 2) Management efficiency in terms of risk control and management and the return of each banking institution is a relevant factor to explain bank failure after dollarization, having previously controlled for some factors such as inflation, the financial intermediation rate, and the leverage of the financial system; 3) Bank profitability measured through ROE exhibits a negative 
effect on the probability of bank failure, a result that is consistent with the literature (Oliveira et al. 2015) and means that a higher level of profitability of institutions decreases their probability of bankruptcy. As expected, the portfolio NPL ratio has a positive coefficient. This suggests that higher levels of delinquency are associated with a greater effect on the probability of bankruptcy of the financial institution (Lafuente, 2001; GonzálezHermosillo, 1999).

The results obtained with the proposed model and the conclusions drawn so far are in line with Korobkin's theory (1991), insofar as this theory states that the understanding of a company's financial difficulties should consider a wide range of not only economic but also qualitative, political, and social factors on which corporate insolvency may have an impact. Thus, the model incorporated not only financial ratios but also an amalgamation of variables related to company management, the macroeconomic, social, and political environment, as well as the general situation of the national financial system itself, resulting in several of these statistically significant variables and especially the variable that determines the political-economic decision to establish dollarization in the country. In addition, the theory establishes the need to consider the dynamic mutation of the factors in play when comparing available resources with human life, which grow and decrease at different rates throughout their useful life; and these depend on an amalgam of characteristics. Thus, the study sample considered private banks (as well as the determinants of bankruptcy) at different points in time throughout their lives and independently. This cross-sectional data analysis is closely aligned with the fields of applied microeconomics, such as labor and urban economics, public finance, industrial organization, etc. as data on individuals, households, firms, and cities at a given point in time are important for testing microeconomic hypotheses and evaluating economic policies.

On the other hand, the limited information on some financial indicators suggested by the Basel Committee - such as the liquidity coverage ratio - represents a challenge for Ecuadorian banks; incorporating it into the model can address issues related to banking liquidity risk.

Considering the discrimination thresholds established by Anderson (2007), the results show that the model has high levels of discrimination capacity: 1) it correctly predicts $95 \%$ of the observations; 2 ) in terms of discrimination between bankruptcy and nonbankruptcy, the ROC curve reaches a value of $82 \%$; 3 ) for the development sample, there is a KS of 54\% and for the validation sample, a $\mathrm{KS}$ value of $52 \%$ is obtained.

This study seeks to be a complement to on-site supervision. The models are one more tool for the supervisor in their quest to achieve efficient control that leads to a more robust and strengthened financial system, since it provides early warning signs of the deterioration of a financial institution in order to take corrective measures and reduce bankruptcy risk and subsequent bank contagion. The estimated alert periods largely coincide with the actual periods of bank fragility in Ecuador (Figure 8.).

Finally, in methodological terms, there are some interesting extensions that could be pursued. One example would be a more dynamic analysis that considers temporal and idiosyncratic variations in the unobservable behavior from a cross-sectional and time series perspective, as well as observable and unobservable individual heterogeneity. An interesting way to incorporate these aspects would be through modeling using panel data, in our case unbalanced panel data. In general, panel data models are more efficient than cross-sectional modeling, since observing an individual over multiple periods reduces variance compared to repeated random observations of individuals. There is also the possibility of establishing hierarchical structures, for example using bank sizes. In general, this type of modeling is more complicated but it provides an evident dynamic regarding economic behavior.

\section{REFERENCES}

Alaka, H. A., Oyedele, L. O., Owolabi, H. A., Ajayi, S. O., Bilal, M., \& Aki- nade, O. O. (2017). Methodological approach of construction business failure prediction studies: A review. Construction Management and Economics, 34 (11), 808-842 .

Alaka, H. A., Oyedele, L. O. , Owolabi, H. A., Oyedele, A. A. , Akinade, O. O. , Bilal, M. , et al. (2018). Critical factors for insolvency prediction: Towards a theoretical model for the construction industry. International Journal of Construction Management, 17 (1), 25-49 .

Altman, E. (1968). Financial Ratios, Discriminant Analysis and the Prediction of Corporate Bankruptcy. The Journal of FINANCE, XXIII, 589-609.

Anderson, R. (2007). The Credit Scoring Toolkit: Theory and Practice for Retail Credit Risk Management and 
Decision Automation. Oxford University Press, USA: Oxford New York.

Arias, X. (2015). Estudio de Vulnerabilidad Financiera. Superintendencia de Bancos y Seuros del Ecuador. Subdirección de Estudios SBE.

Ayala, R. (1999). Modelos de Alerta Temprana para Crisis Financieras. El Caso Ecuatoriano: 1994-1997. Banco Central del Ecuador. Notas Técnicas (51), 1-33.

Banco Central del Ecuador - BCE (2008). Memorias anuales 1980 - 2007. Quito: Estadísticas Banco Central del Ecuador.

Bedri Kamil Onur Tas, Selahattin Togay (2014). Efectos de la dolarización oficial en una pequeña economía abierta: el caso de Ecuador. Investigación Económica Volume 73, Issue 290, Pages 51-86

Calvo G.A. (2001). Capital Markets and the Exchange Rate with Special Reference to the Dollarization Debate in Latin America. Journal of Money, Credit, and Banking, 33 (2), pp. 312-334

Caprio, G., \& Klingebiel, D. (2003). Episodes of Systemic and Borderline Financial Crises.

Demirguc-Kunt, A., \& Detragiache, E. (1997). The Determinants of Banking Crises: Evidence from Developing and Developed Countries. International Monetary Found, Working paper(No. WP/97/106).

Firth, D. (1993). Bias Reduction of Maximum Likelihood Estimates. Biometrika, 80(1), 27-38.

Fischer, S. (1993). The Role of Macroeconomic Factors in Growth. Journal of Monetary Economics, 32(3), 485-512.

Foster, D., Stine, R. (2004). Variable Selection in Data Mining Building a Predictive Model for Bankruptcy. Journal of the American Statistical Association, 99(466).

Gao, S, Shen, J. (2007):Asymptotic properties of a double penalized maximum likelihood estimator in logistic regression. In: Statistics and Probability Letters 77: $925-930$

González-Hermosillo, B. (1999). Indicadores de alerta de las crisis bancarias. Finanzas y Desarrollo, 37-43.
Greene, W. (2012). Econometric Analysis (Seventh ed.). New York, USA: PEARSON.

Hernández, M., \& Wilson, N. (2013). Financial distress and bankruptcy prediction among listed companies using accounting, market and macroeconomic variables. International Review of Financial Analysis, 30, 394-419.

Horta, I.M. and Camanho, A.S. (2013) Company failure prediction in the construction industry. Expert Systems with Applications, 40(16), 6253-7.10.1016/j. eswa.2013.05.045

Huang, S. C. , Tang, Y. C. , Lee, C. W. , \& Chang, M. J. (2012). Kernel local Fisher discriminant analysis based manifold-regularized SVM model for financial distress predictions. Expert Systems with Applications, 39 (3), 3855-3861.

Jeong, C. , Min, J. H. , \& Kim, M. S. (2012). A tuning method for the architecture of neural network models incorporating GAM and GA as applied to bankruptcy prediction. Expert Systems with Applications, 39 (3), 3650-3658

Kaminsky, G., \& Reinhart, C. (1999). The American Economic Review. Retrieved from https://www.macroeconomics. tu-berlin.de/fileadmin/fg124/financial_crises/literature/ Kaminsky__Reinhart_1999_.pdf

King, G., \& Zeng, L. (2001). Logistic Regression in Rare Events Data. Political Analysis, 9(2), 137-163.

Korobkin, D.R. (1991), Rehabilitating values: A jurisprudence of bankruptcy. Columbia Law Review, 91, 717.

Lafuente, D. (2001). La crisis de los bancos privados en el Ecuador: Una aplicación de los modelos de duración. Banco Central del Ecuador. Cuestiones Económicas, 17(3), 7-37.

Lee, K., Booth, D., \& Alam, P. (2005). A comparison of supervised and unsupervised neural networks in predicting bankruptcy of Korean firms. Expert Systems with Applications, 29 (1), 1-16.

Minda A. (2005). Full Dollarization: A last resort solution to financial instability in emerging countries? The European Journal of Development Research, 17 (2), pp. 289-316. 
Mintzberg, H. (1987). The strategy concept I: Five Ps for strategy. California management review, 30(1), 11-24

Mselmi, N., Lahiani, A., \& Hamza, T. (2017). Financial distress prediction: The case of French small and mediumsized firms. International Review of Financial Analysis, $50,67-80$.

Naranjo, M. (2003). La dolarización de la economía del Ecuador: tres años después. Cuestiones Económicas, 19(1-3), 115-155.

Naranjo Chiriboga, M. (2018, enero 15). Incidencia de la dolarización sobre la economía ecuatoriana, 2000 - 2015. Semestre Económico, 21(46), 95-122. https://doi.org/ https://doi.org/10.22395/seec.v21n46a4

Oliveira, A., Vitorino, F., \& Brandao, E. (2015). Bank Failure and the Financial Crisis: An Econometric Analysis of U.S. Banks. SSRN.

Peduzzi, P., Concato, J., Kemper, E., Holford T. R., Feinstein, A. R. (1996): A Simulation Study of the Number of Events per Variable in Logistic Regression Analysis. In: Journal of Clinical Epidemiology 49: 1373 - 1379.

Páez, L. (2014, Mayo). Vulnerabilidades de sistemas bancarios en una economía dolarizada, caso Ecuador: 2003-2012. Banco Central del Eucador. Cuestiones Económicas, 43-96.

Rojas-Suarez, L. (1998). "Early Warning Indicators of Banking Crises: What Works for Emerging Markets?, with applications to Latin America”. Manuscrito, Banco Interamericano de Desarrollo. https://www.researchgate. net/publication/260634733_Early_Warning_Indicators_ of_Banking_Crises_What_Works_for_Emerging_Markets_ With_Applications_to_Latin_America
Tas, B. K. O., \& Togay, S . (2014). Efectos de la dolarización oficial en una pequeña economía abierta: El caso de Ecuador. Investigación Económica, 73(290), 51-86.

Tseng, F. M., \& Hu, Y. C. (2010). Comparing four bankruptcy prediction models: Logit, quadratic interval logit, neural and fuzzy neural networks. Expert Systems with Applications, 37 (3), 1846-1853 .

Uquillas A, González C. (2018) . Determinantes macro y microeconómicos para pruebas de tensión de riesgo de crédito: un estudio comparativo entre Ecuador y Colombia basado en la tasa de morosidad. Ensayos sobre Política Económica. Vol 35. No. 84.

Williams, R. (2017). Analyzing Rare Events with Logistic Regression. Notre Dame. https://www.studocu.com/ en-us/document/university-of-notre-dame/categoricaldata-analysis/lecture-notes/analyzing-rare-events-withlogistic-regression/1194074/view

Wooldridge, J. (2010). Econometric Analysis of Cross Section and Panel Data (Second ed.). The MIT Press.

Yang, Z., You, W., \& Ji, G. (2011). Using partial least squares and support vector machines for bankruptcy prediction. Expert Systems with Applications, 38 (7), 8336-8342 .

Zhang, Y., Shuihua, W., Genlin, J. (2013), A rule-based model for bankruptcy prediction based on an improved genetic ant colony algorithm. Mathematical Problems in Engineering, 2013, 1-10.

Zhou, L., Lai, K., \& Yen, J. (2014), Bankruptcy Prediction Using SVM Models with a New Approach Combine Features Selection and Parameters Optimization. International Journal of Systems Science, 2014, 1-28. 


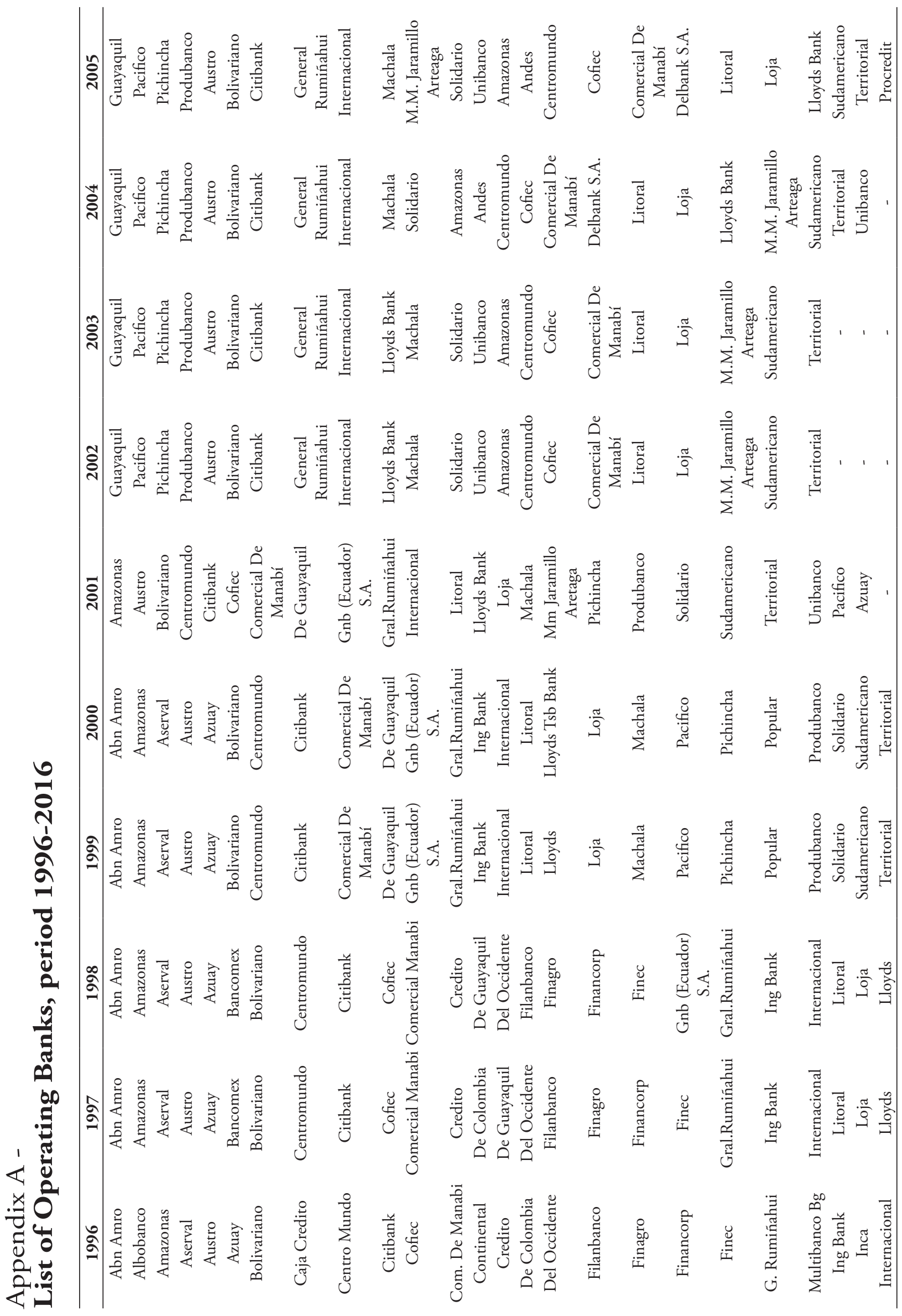




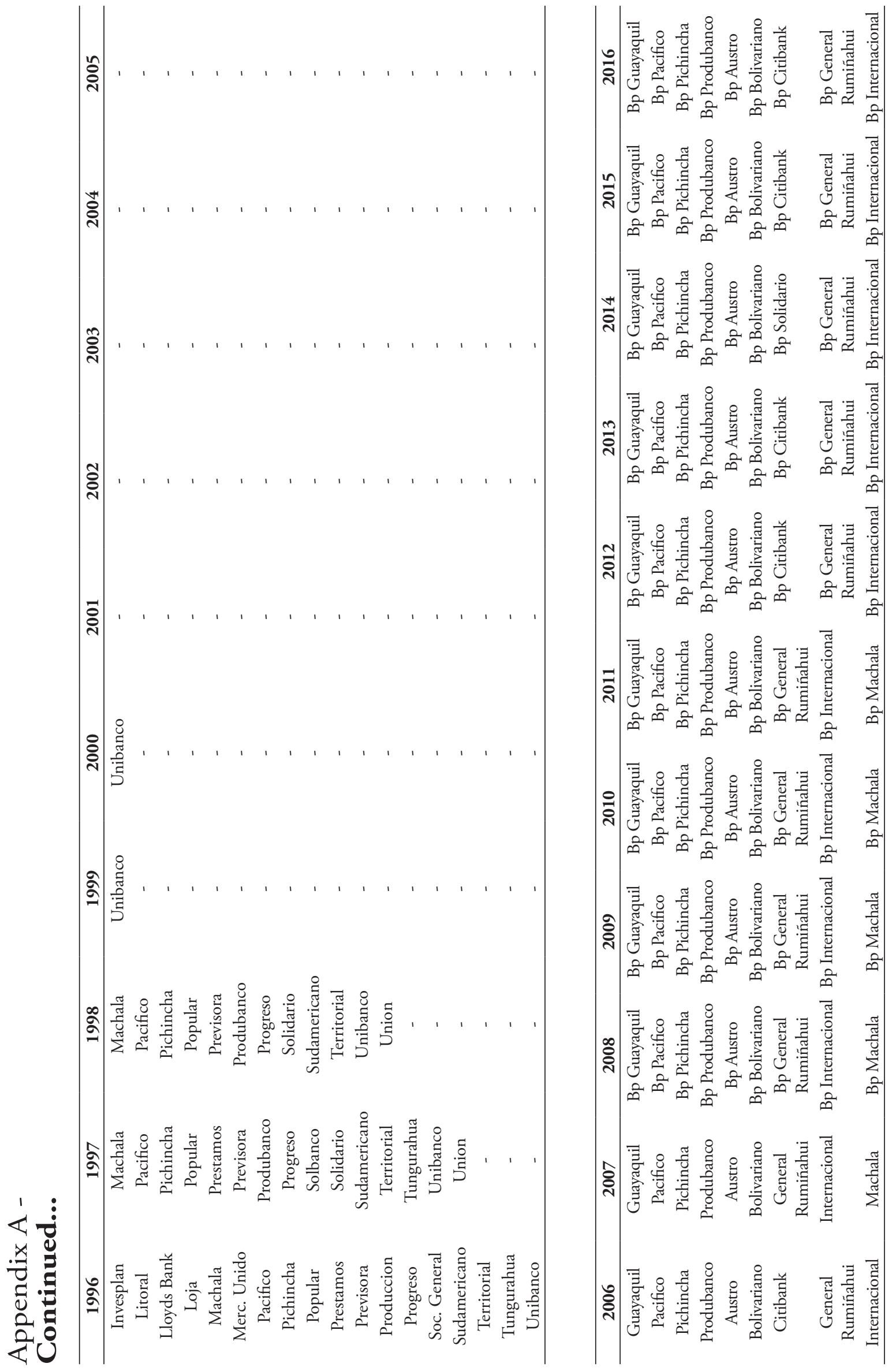




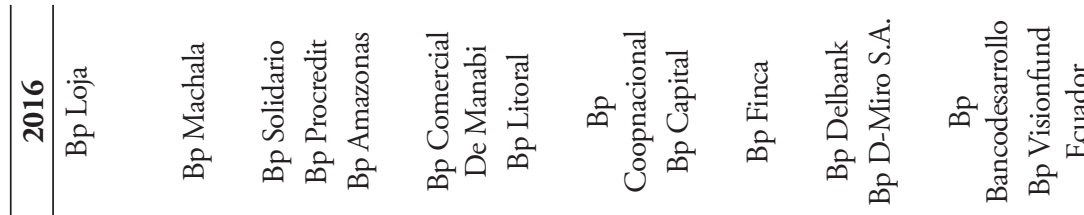

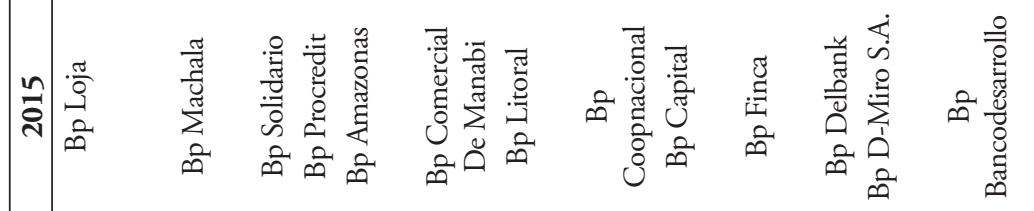

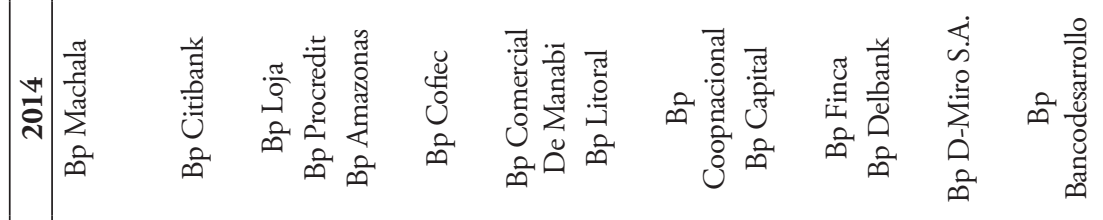

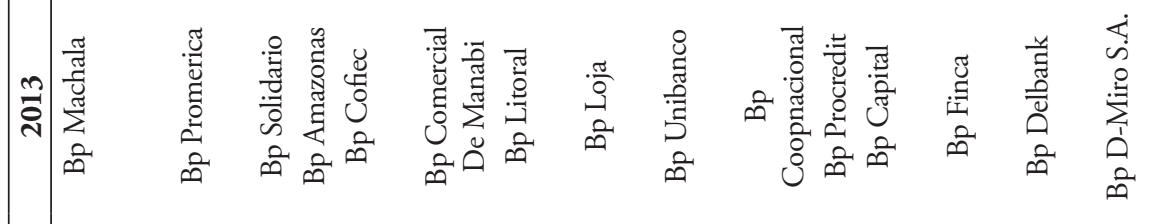

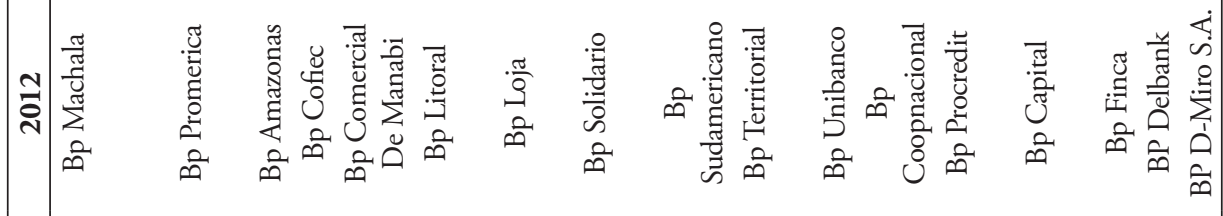

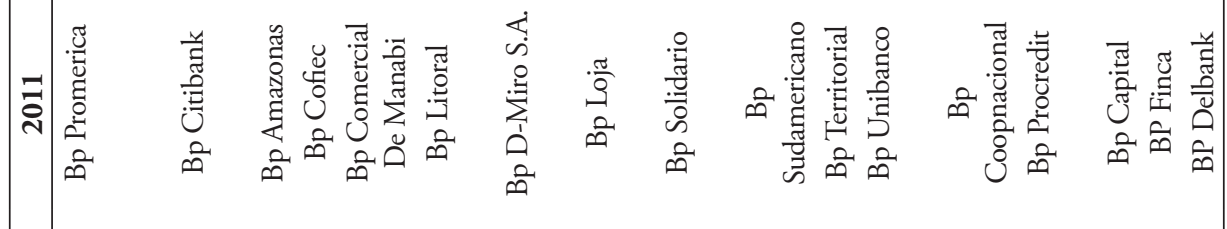

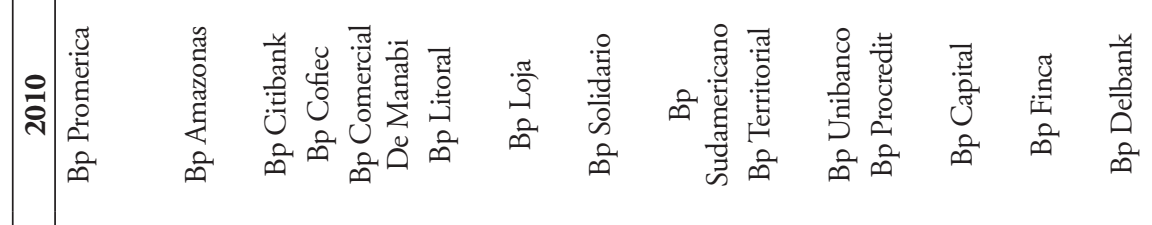

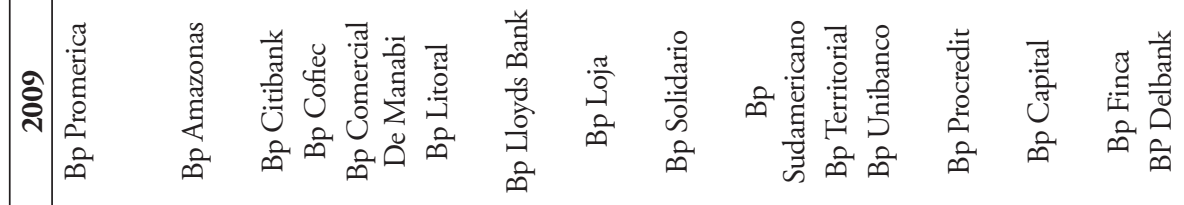

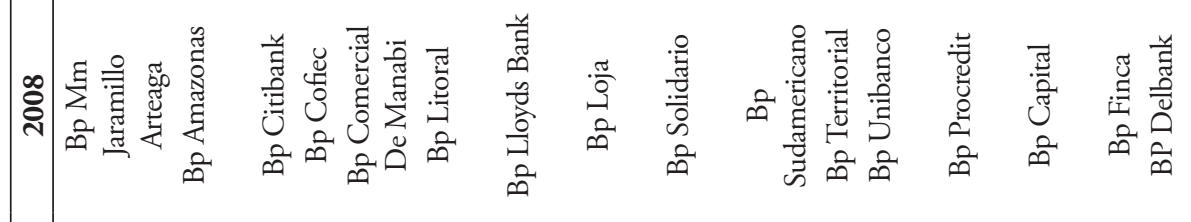

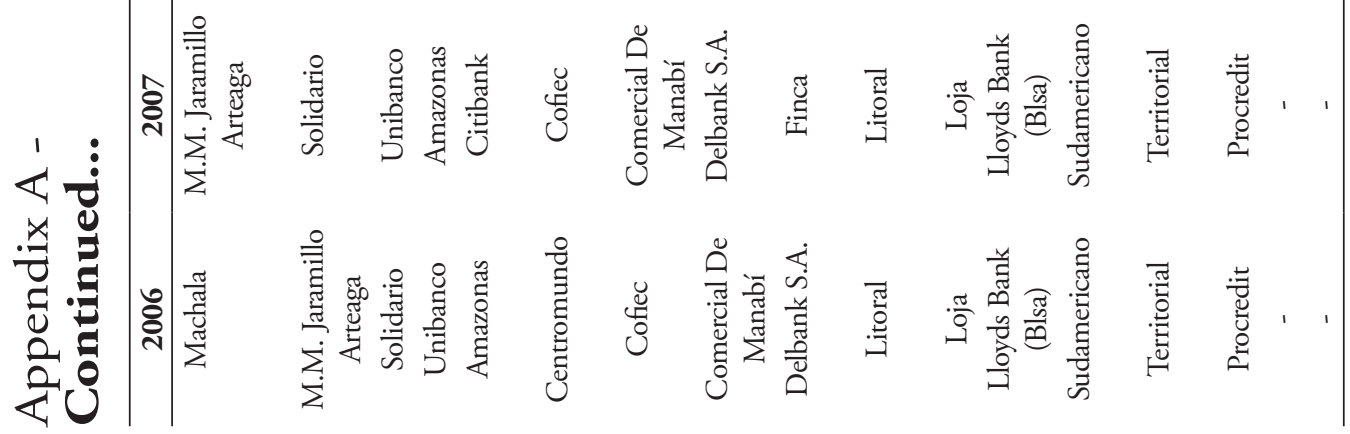




\section{Appendix B -}

\section{Independent Variables Considered in the Study}

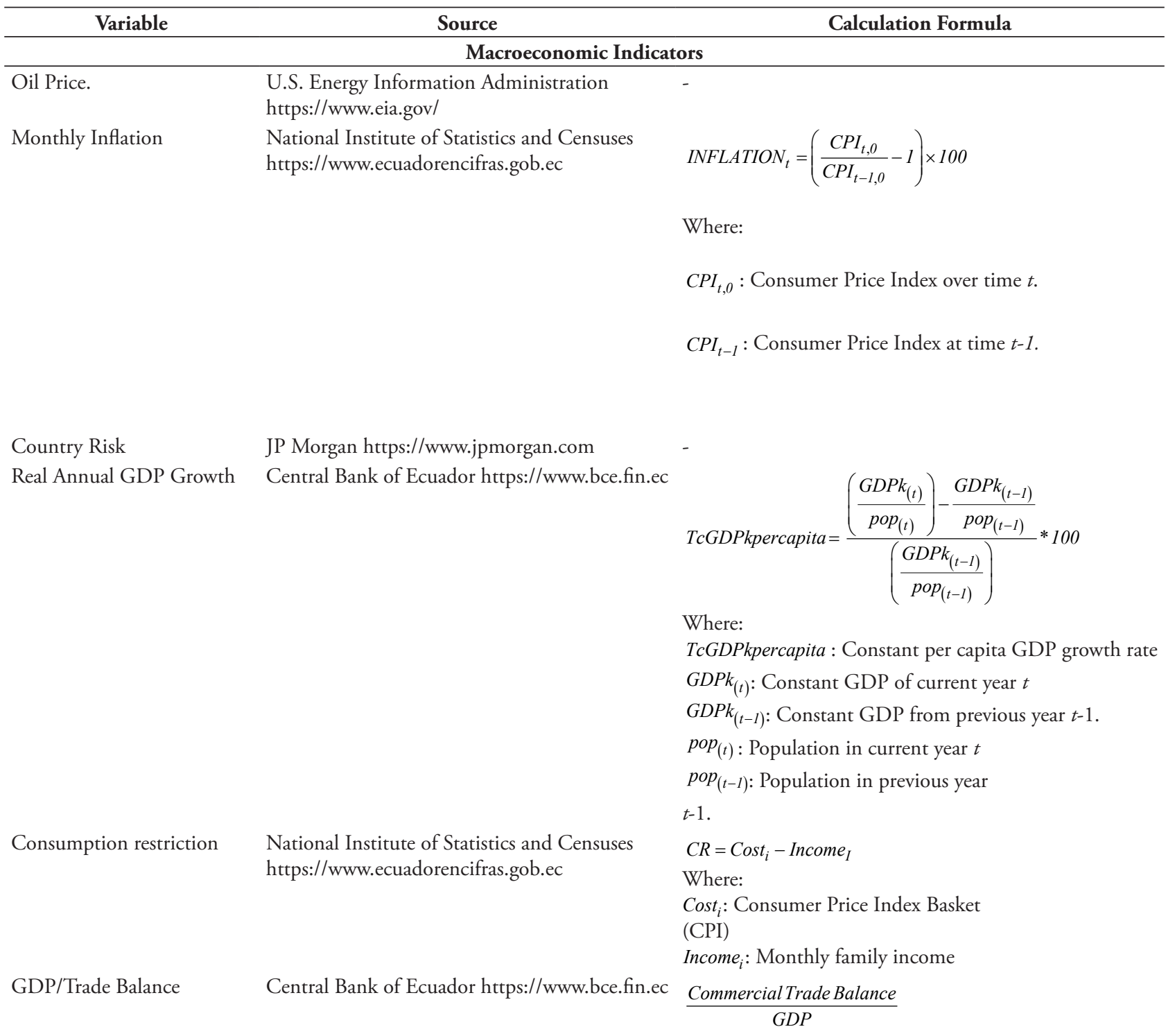

\section{Banking System Indicators}

Financial Spread

GDP/Credit

GDP/Credit

Funding

Leveraging

Liquidity
Central Bank of Ecuador https://www.bce.fin.ec Active Rate-Passive Rate

Central Bank of Ecuador https://www.bce.fin.ec

\section{$\frac{\text { CreditVolume }}{\text { CEAI }}$}

Where: Conjunctural Economic Activity Index

CEAI: Conjunctural Economic Activity

Index

Central Bank of Ecuador https://www.bce.fin.ec $\frac{\text { Credit }}{G D P}$

Central Bank of Ecuador https://www.bce.fin.ec Total Assets

$\overline{\text { Total Liabilities }}$

Central Bank of Ecuador https://www.bce.fin.ec

$\underline{\text { Total Assets }}$

Total Equity

Central Bank of Ecuador https://www.bce.fin.ec_Available Funds 


\section{Appendix B - \\ Continued...}

\begin{tabular}{|c|c|c|}
\hline Variable & Source & Calculation Formula \\
\hline Capture/GDP & Central Bank of Ecuador https://www.bce.fin.ec & $\frac{\text { Captures }}{G D P}$ \\
\hline $\begin{array}{l}\text { Capital and Reserves / } \\
\text { Credit Volume. }\end{array}$ & Central Bank of Ecuador https://www.bce.fin.ec & $\frac{\text { Capital \& Reserves }}{\text { CreditVolumen }}$ \\
\hline Delinquency Portfolio & Central Bank of Ecuador https://www.bce.fin.ec & $\frac{\text { Unproductive Portfolio }}{\text { Gross Portfolio }}$ \\
\hline \multicolumn{3}{|c|}{$\begin{array}{l}\text { Idiosyncratic Indicators } \\
\end{array}$} \\
\hline $\begin{array}{l}\text { Productive Assets / Total } \\
\text { Assets }\end{array}$ & $\begin{array}{l}\text { Superintendency of Banks https://www. } \\
\text { superbancos.gob.ec }\end{array}$ & $\frac{\text { Productive Assets }}{\text { Total Assets }}$ \\
\hline $\begin{array}{l}\text { Productive Assets/Cost- } \\
\text { generating Liabilities }\end{array}$ & $\begin{array}{l}\text { Superintendency of Banks https://www. } \\
\text { superbancos.gob.ec }\end{array}$ & $\frac{\text { Productive Assets }}{\text { Cost-generating Liabilities }}$ \\
\hline Size of the bank & $\begin{array}{l}\text { Superintendency of Banks https://www. } \\
\text { superbancos.gob.ec }\end{array}$ & $\ln ($ Total assets $)$ \\
\hline Capital \& Reserves / Assets & $\begin{array}{l}\text { Superintendency of Banks https://www. } \\
\text { superbancos.gob.ec }\end{array}$ & $\frac{\text { Capital \& Reserves }}{\text { Total Assets }}$ \\
\hline Fiscal Year Results / Assets & $\begin{array}{l}\text { Superintendency of Banks https://www. } \\
\text { superbancos.gob.ec }\end{array}$ & $\frac{\text { Fiscal Year Results }}{\text { Total Assets }}$ \\
\hline Fiscal Year Results / Assets & $\begin{array}{l}\text { Superintendency of Banks https://www. } \\
\text { superbancos.gob.ec }\end{array}$ & $\frac{\text { Fiscal Year Results }}{\text { Assets }}$ \\
\hline Gross Portfolio / Total Assets & $\begin{array}{l}\text { Superintendency of Banks https://www. } \\
\text { superbancos.gob.ec }\end{array}$ & $\frac{\text { Gross Portfolio }}{\text { Total Assets }}$ \\
\hline $\begin{array}{l}\text { Fiscal Year Results / Volume } \\
\text { of Credit System }\end{array}$ & $\begin{array}{l}\text { Superintendency of Banks https://www. } \\
\text { superbancos.gob.ec }\end{array}$ & $\frac{\text { Fiscal Year Results }}{\text { Volumen of Credit System }}$ \\
\hline Funding & $\begin{array}{l}\text { Superintendency of Banks https://www. } \\
\text { superbancos.gob.ec }\end{array}$ & $\frac{\text { Total Assets }}{\text { Total Liabilities }}$ \\
\hline Leveraging & $\begin{array}{l}\text { Superintendency of Banks https://www. } \\
\text { superbancos.gob.ec }\end{array}$ & $\frac{\text { Total Assets }}{\text { Total Equity }}$ \\
\hline Portfolio Delinquency & $\begin{array}{l}\text { Superintendency of Banks https://www. } \\
\text { superbancos.gob.ec }\end{array}$ & $\frac{\text { Nonperforming Portfolio }}{\text { Gross Portfolio }}$ \\
\hline $\begin{array}{l}\text { Coverage of problematic } \\
\text { portfolios }\end{array}$ & $\begin{array}{l}\text { Superintendency of Banks https://www. } \\
\text { superbancos.gob.ec }\end{array}$ & $\frac{\text { Provisions }}{\text { Nonperforming loan portfolio }}$ \\
\hline $\begin{array}{l}\text { Operating Costs / Financial } \\
\text { Margin }\end{array}$ & $\begin{array}{l}\text { Superintendency of Banks https://www. } \\
\text { superbancos.gob.ec }\end{array}$ & $\frac{\text { Operating Costs }}{\text { Financial Margen }}$ \\
\hline ROE & $\begin{array}{l}\text { Superintendency of Banks https://www. } \\
\text { superbancos.gob.ec }\end{array}$ & $\frac{\text { Results of the Financial Year }}{\text { Average Equity }}$ \\
\hline ROA & $\begin{array}{l}\text { Superintendency of Banks https://www. } \\
\text { superbancos.gob.ec }\end{array}$ & $\frac{\text { Results of the Financial Year }}{\text { AverageTotal Assets }}$ \\
\hline Liquidity Index & $\begin{array}{l}\text { Superintendency of Banks https://www. } \\
\text { superbancos.gob.ec }\end{array}$ & $\frac{\text { Available Funds }}{\text { Total short-term deposits }}$ \\
\hline
\end{tabular}




\section{Authors:}

1. Adriana Uquillas, PhD, Universidade de Sao Paulo, SP, Brazil.

E-mail: adriana.uquilas@epn.edu.ec

ORCID

(D) 0000-0003-1052-6260

2. Francis Flores, Escuela Politécnica Nacional, Quito, Equador.

E-mail: francis.flores@epn.edu.ec

ORCID

(D) $0000-0002-0983-4250$

\section{Contribution of each author}

\begin{tabular}{lcc}
\hline \multicolumn{1}{c}{ Contribution } & Adriana Uquillas & Francis Flores \\
\hline 1. Definition of research problem & $\sqrt{ }$ \\
2. Development of hypotheses or research questions (empirical studies) & $\sqrt{ }$ \\
3. Development of theoretical propositions (theoretical work) & $\sqrt{ }$ \\
4. Theoretical foundation/literature review & $\sqrt{ }$ \\
5. Definition of methodological procedures & $\sqrt{ }$ \\
6. Data collection & & $\sqrt{ }$ \\
7. Statistical analysis & $\sqrt{ }$ \\
8. Analysis and interpretation of data & $\sqrt{ }$ \\
9. Critical revision of the manuscript & $\sqrt{ }$ \\
10. Manuscript writing & $\sqrt{ }$ \\
11. Other & & $\sqrt{ }$ \\
\hline
\end{tabular}

